\title{
Application of domestic high-resolution satellite data On Geological Hazard Monitoring in Coal Mining Areas
}

\author{
Wang $\mathrm{Jie}^{1}$,Wang $\mathrm{Hao}^{1}$, Yao Weiling ${ }^{1}$,Wang Haiqing ${ }^{1}$, and $\mathrm{Li} \mathrm{Li}^{1}$ \\ ${ }^{1}$ China Aero Geophysical Survey \& Remote Sensing Center for Land and Resources, Beijing
}

\begin{abstract}
Rapid development of remote sensing technology has become an important means of geological hazards monitoring. Domestic high- resolution satellite data such as TH-1, ZY-3, GF1/2 and BJ-2, because of its high quality and low price, are more and more widely used in the field of geology. However, there are still some problems in data processing and the research on domestic satellite data in coal mining geological hazards monitoring is not much. So it needs further research and application. This paper aims to establish a set of technology scheme for dynamic monitoring and analysis of geological hazards in coal mining collapse area based on domestic high-resolution satellite. We selected the Xinjiang Uygur Autonomous Region Midong District of Urumqi where geological disasters are more serious as the study area, compared and analyzed the domestic high-resolution satellite images based on the TH-1 (2014), GF-1 (2015), BJ-2 (2016). This paper identified dynamic change of geologic hazard, set up the symbol of interpretation, evaluated and explored the practicability of land disaster investigation and dynamic monitoring with domestic high-resolution satellite. Based on the dynamic monitoring with domestic high-resolution satellite data from 2014 to 2016, we found that the geological disasters such as ground collapse and ground cracks are increasing. We suggest that it should be planned first, and exploitation should be scientific. It is necessary to strengthen the restoration of governance.
\end{abstract}

\section{Introduction}

Geological disasters such as mining subsidence and so on are becoming more and more serious because of long-term, large-scale coal mining. It not only destroys the ecological environment of the mining area, but also seriously threatens the life and property safety of the people in the mining area, which has caused great losses to the social economy. Therefore, the use of remote sensing technology to study the image characteristics of geological disasters such as coal mining subsidence has important theoretical significance and practical value for the study of geological disasters in coal mining area. Under this background, many researchers have carried out extensive research on mine geological environment disasters. ${ }^{[1-4]}$

The remote sensing investigation of geological disasters in our country mainly depends on the foreign satellite data. The data source is unstable, the data is scattered, the cost of procurement is high, and the timeliness of the investigation is often not sure. It is difficult to realize the real-time and systematic application of the geological environmental disaster monitoring in the mining area. In recent years, China has launched a series of resources and environmental satellites, especially the domestic high resolution satellites, such as TH-1, ZY-3, GF-1, GF-2, BJ-2and so on. The ability to earth observation is greatly improved and the spatial resolution of the satellite reaches the meter level, which can meet the requirements of geological disaster monitoring with different scale. It provides sufficient data sources for the application of domestic satellites in mine geological hazard monitoring. Some Chinese scholars also actively carry out research on the application of domestic satellite in remote sensing of land and resources, and have achieved good results. It has proved the feasibility and efficiency of the domestic satellite in the monitoring of geological disasters. However, there are still some problems in the data processing because of the short time of the high score series of satellites, less data accumulation and some problems in the data processing ${ }^{[5-10]}$.

In this paper, the area of the mined subsidence geological disaster in Urumqi, the Xinjiang Uygur Autonomous Region, the Xinjiang Uygur Autonomous Region, is selected as the experimentation area. Through the comparison and analysis of the three stage high resolution satellite images of 2014-2016, the dynamic change of geological disasters is carried out and the high grade data made in China is analyzed and summed up in the geological disaster in Xinjiang area. In order to provide some ideas and reference for geological disaster monitoring in the future, the practical characteristics of the application of the disaster dynamic monitoring are evaluated. 


\section{Research area survey}

The research area is located in the territory of Urumqi, the Xinjiang Uygur Autonomous Region (Figure 1), with an area of about $84.89 \mathrm{~km} 2$. The terrain is dominated by hills and low mountains. The strata are relatively stable, and the surface is dominated by loose sandstone. The study area is rich in coal resources, the number of coal mines is large, underground mining is concentrated in coal mines, and 15 coal mines are involved in the area, all of which are underground mining. In a small range, there is a large scale of mining and production. The problem of mining subsidence caused by coal mining is prominent, and the mining subsidence area continues to expand, which is the easy area and high incidence area of mine geological disasters in Xinjiang area.

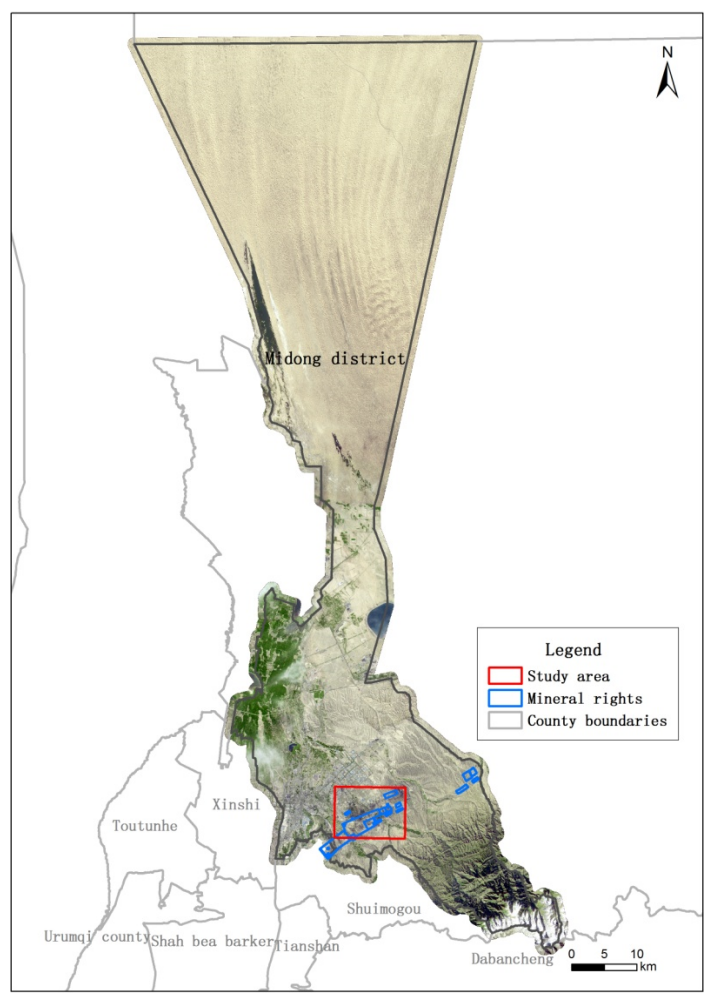

Fig.1 The study area geographic location

\section{Remote sensing data source and research method}

\subsection{Formatting the title}

The data derive from China's high resolution remote sensing images $\mathrm{TH}-1, \mathrm{GF}-1$ and $\mathrm{BJ}-2$, and remote sensing images were obtained in 2014, 2015 and 2016 respectively ${ }^{[1,12]}$. Its parameters are shown in Table 1.

Tab.1 Perameters of Domestic Satellite

\begin{tabular}{|c|c|c|c|}
\hline $\begin{array}{c}\text { Homemade satellite } \\
\text { data types }\end{array}$ & TH-1 & GF-1 & BJ-2 \\
\hline $\begin{array}{c}\text { Satellite height } / \mathrm{km} \\
\begin{array}{c}\text { Radiant quantization } \\
\text { level }\end{array}\end{array}$ & 500 & 500 & 651 \\
\hline $\begin{array}{c}\text { spatial resolution } / \mathrm{m} \\
\text { Scan width } / \mathrm{km}\end{array}$ & $2 / 10$ & $10 \mathrm{bit}$ & $10 \mathrm{bit}$ \\
\hline $\begin{array}{c}\text { Satellite revisit cycle } \\
\text { /day }\end{array}$ & 50 & 60 & $1 / 4$ \\
\hline \multirow{2}{*}{\begin{tabular}{c} 
Spectral band $/ \mathrm{nm}$ \\
\cline { 2 - 4 }
\end{tabular}} & B:430-520 & B:450-520 & B:440-510 \\
\cline { 2 - 5 } & NIR:520-610 & G:520-590 & G:510-590 \\
\cline { 2 - 5 } & P:510-690 & R:630-690 & R:600-670 \\
\cline { 2 - 5 } & NIR:770-890 & NIR:760-910 \\
\hline
\end{tabular}

\subsection{Research methods}

In this paper, a series of pre-processing research on remote sensing images, such as orthophoto correction, best color synthesis, image registration, image fusion, image mosaic, and image cutting, is studied in this paper, and the most suitable for mining geological hazard information extraction is selected. The mining geological disaster information is extracted by visual interpretation, and the geological disaster interpretation marks are established. On this basis, the field exploration is combined, and the results are compared and verified. The technical process is shown in Figure 2, and the data processing results are shown in Figure 3. 


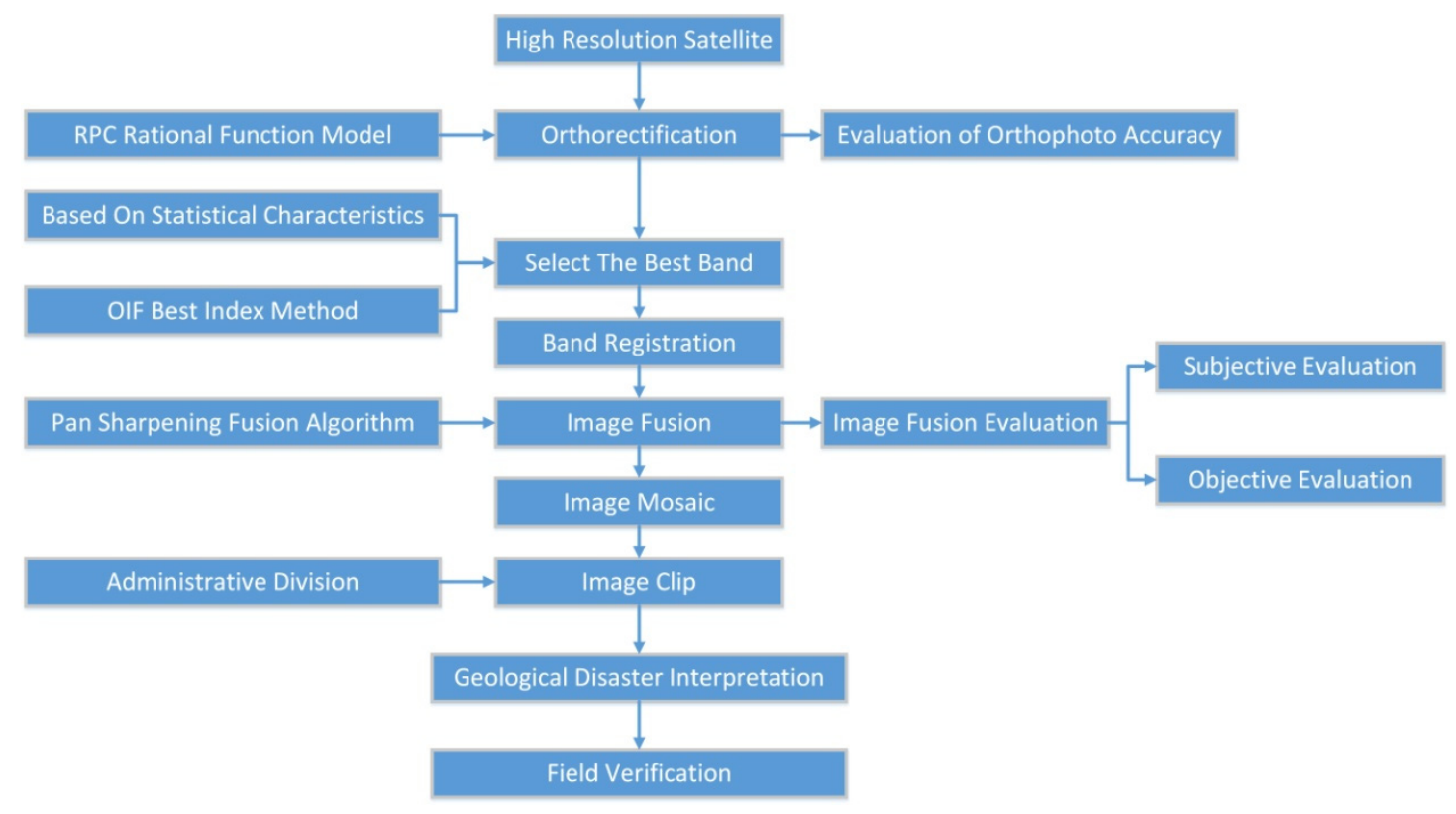

Fig. 2 Process of remote sensing dynamic monitoring

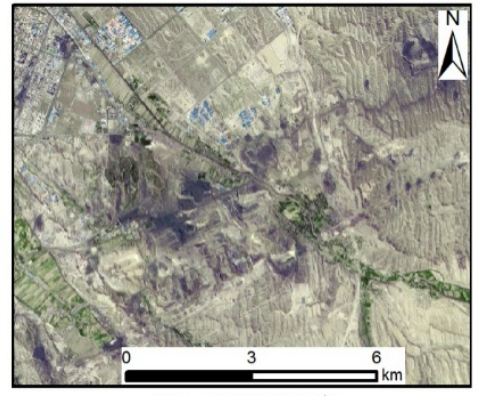

(a) TH-1 satellite image

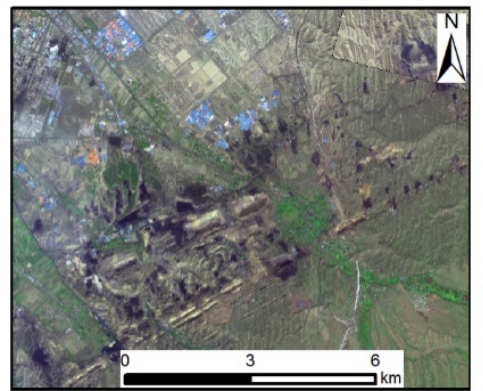

(b) GF-1satellite image

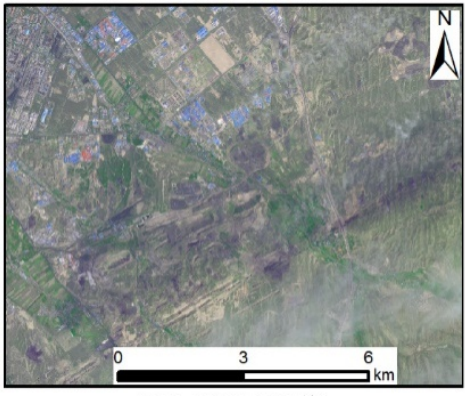

(c) BJ-2satellite image

Fig. 3 Processing results of remote sensing images in study area

\section{The establishment of interpretation symbols and field verification}

\subsection{Interpretation symbols}

Through the analysis of the geological disasters in the study area, it is found that the geological disasters in the mining area are mainly the collapse pits, the ground cracks and the spontaneous combustion of the gangue caused by the Goaf Collapse Caused by the coal mining, and summarize the characteristics of the geological disasters. In addition, according to the geosciences knowledge such as the relevant attributes of the ground objects, the subsidence area can be indirectly identified from the remote sensing images (Fig. 4).

\subsubsection{Collapse pit}

Due to the sudden changes in the terrain, the collapse pit causes spectral differences, and the hue has a certain change compared with the surrounding environment, and the vegetation cover is sparse or not covered with vegetation. There are two forms of Goaf Collapse in the form of beaded collapse pit and trough collapse pit. The beaded collapse crater is generally round or oval, with porphyritic images. The area of collapse is generally several hundred square meters. The groove collapse pit is large in size, usually in a strip shape. The tone is deep color with light hue. The surface diameter is more than ten meters to tens of meters, and deep tens of centimeters to more than ten meters. The stability is poor, and the degree of geological hazards is common. The old collapse pit often forms depression and has accumulated water and deep shade.

\subsubsection{Ground fissure}


The trend of ground fissure is generally inconsistent with the trend of topography and geomorphology unit, and may be cut through different landform units. The ground fissure in the remote sensing image is dark linear or banded, generally several meters long to several hundred meters wide, several centimeters wide to several meters, and the vegetation distribution is uneven. The ground cracks are usually formed on the edge of the trough type collapse pit, the cracks are straight, the extension direction is stable, the groups are distributed parallel, and most of them extend from the side of the working face to the other side.

\subsubsection{Spontaneous combustion of coal gangue}

On the image, the spontaneous combustion of coal gangue presents an irregular black gray belt and a patch pattern. The area of open fire area is small, generally occurring in the vicinity of coal mine entrance and cracks Because the temperature of the spontaneous combustion zone of coal seam is high, and there are a large number of harmful gases which are not conducive to the growth of vegetation, so there is little or no vegetation cover in the surrounding vegetation.

\subsubsection{Indirect sign}

Even high-definition images are difficult to identify directly for smaller craters. But the collapse of mining will cause the road to sink and damage the road. In severely damaged sections, mining areas need to rebuild roads in nearby safe areas and bypass the subsidence area. Therefore, road alignment can also be used as an important symbol for identifying geological hazards such as subsidence in high-definition images.
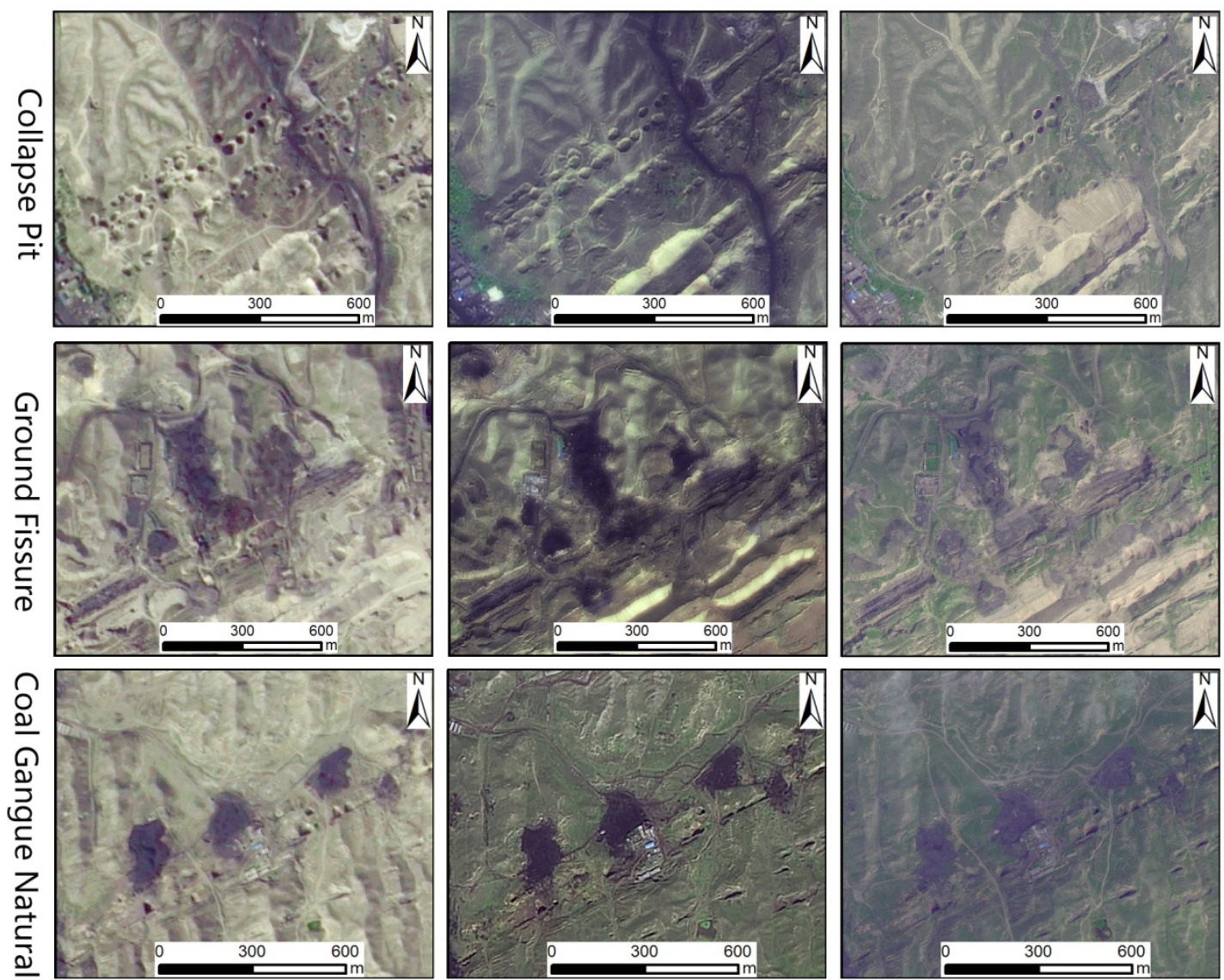

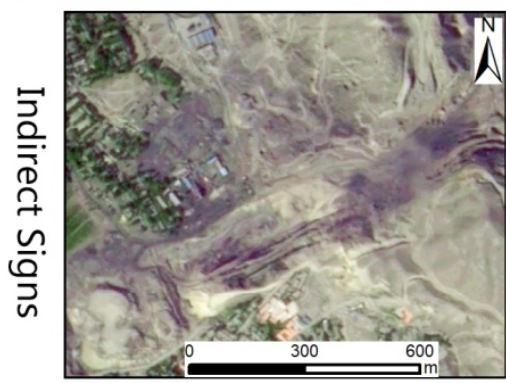

(a) TH-1 satellite image

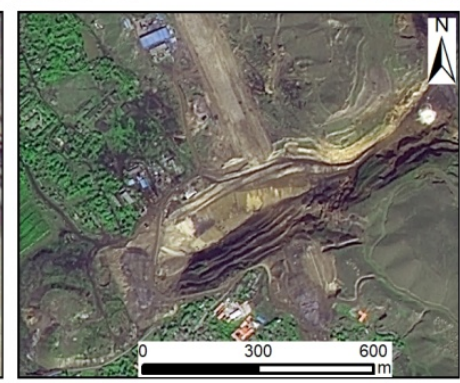

(b) GF-1 satellite image

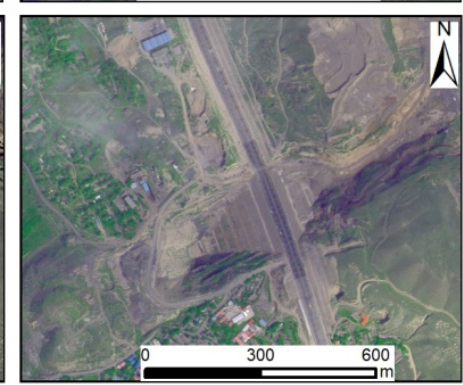

(c) BJ-2 satellite image

Fig.4 Remote sensing image features of coal mining subsidence area 


\subsection{Field verification}

In order to more accurately interpret the geological hazards in mining areas and to verify the accuracy of the interpretation results, we have selected 5 validation areas and carried out a field examination of 55 interpreter spots (Figure 5). The verification results are shown in Table 2, and the accuracy of interpretation is as high as $94 \%$.

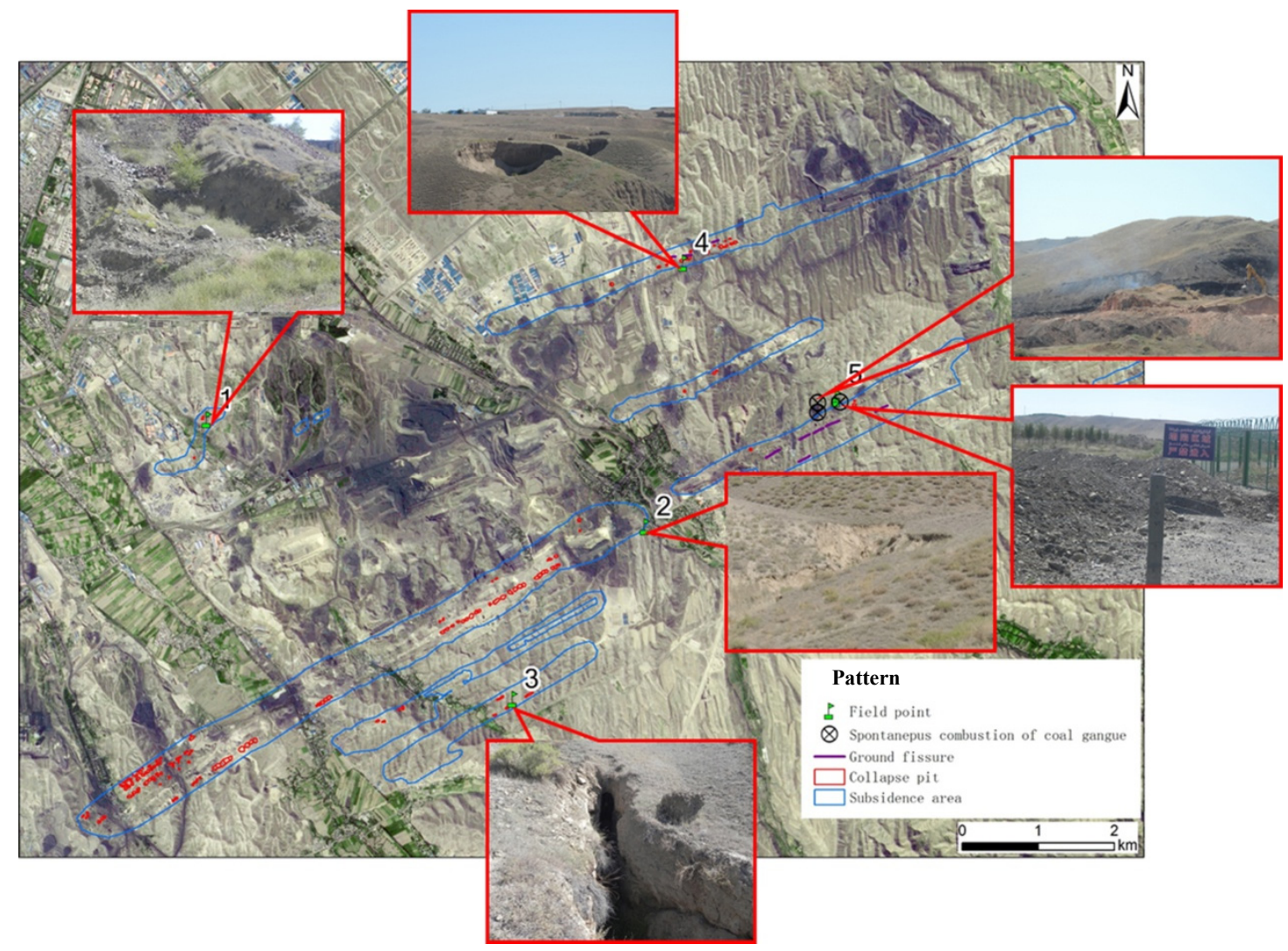

Fig.5 Field distribution and field photos

Tab.2 The results of field verification

\begin{tabular}{|c|c|}
\hline subsidence area & Field description \\
\hline subsidence area -1 & $\begin{array}{l}\text { It was found that the collapse area was located on the side of the highway, and } \\
\text { there were } 4 \text { craters. }\end{array}$ \\
\hline subsidence area -2 & $\begin{array}{l}\text { The target direction distribution has many different craters, and the target area } \\
\text { is distributed continuously. G30 high speed runs through the collapse area. }\end{array}$ \\
\hline subsidence area -3 & $\begin{array}{l}\text { The area can be seen as a strip collapse area, with many rubble, a deep mining } \\
\text { shaft nearby, and a collapse pit. }\end{array}$ \\
\hline subsidence area -4 & $\begin{array}{l}\text { It can be seen that the collapse area is distributed in pieces, the size of the } \\
\text { collapse pits is different, the maximum collapse pit is about } 50 \text { meters in } \\
\text { diameter, and the depth is about } 50 \mathrm{~cm} \text {. There are many ground cracks in the } \\
\text { subsidence area, the whole subsidence area is north-east to the southwest, and } \\
\text { the northeast side has a collapse warning sign. }\end{array}$ \\
\hline subsidence area -5 & $\begin{array}{l}\text { It can be seen that the collapse area is distributed in slices, the size of the } \\
\text { collapse pit is different, and there are many ground cracks in the subsidence } \\
\text { area, and the whole subsidence area is north-east to the southwest, and there is } \\
\text { no warning sign of collapse. }\end{array}$ \\
\hline $\begin{array}{l}\text { Spontaneous combustion of } \\
\text { coal gangue }\end{array}$ & $\begin{array}{l}\text { The coal mine fire fighting construction is being carried out at the scene. There } \\
\text { are many coal fire spontaneous combustion points burning and smoking, and } \\
\text { many excavators and transport vehicles are putting out fires. The target area is } \\
900 \text { meters Northwest for fire fighting engineering headquarters, the name is } \\
\text { three dam coal field fire fighting engineering headquarters. }\end{array}$ \\
\hline
\end{tabular}




\section{Survey results}

Through the dynamic monitoring of the high grade image of China in the three years from 2014 to 2016 in the study area, it is found that the geological disasters such as Goaf Collapse and ground fissure in the study area are increasing, and the monitoring results are shown in Table 3.

In 2014, the study area monitored 8 subsidence areas, including 169 subsidence pits, 8 ground cracks and 1 coal gangue spontaneous combustion points, and the total area of geological disasters was about 1463.2 hectares. In 2015 , the study area was monitored to 8 of the various
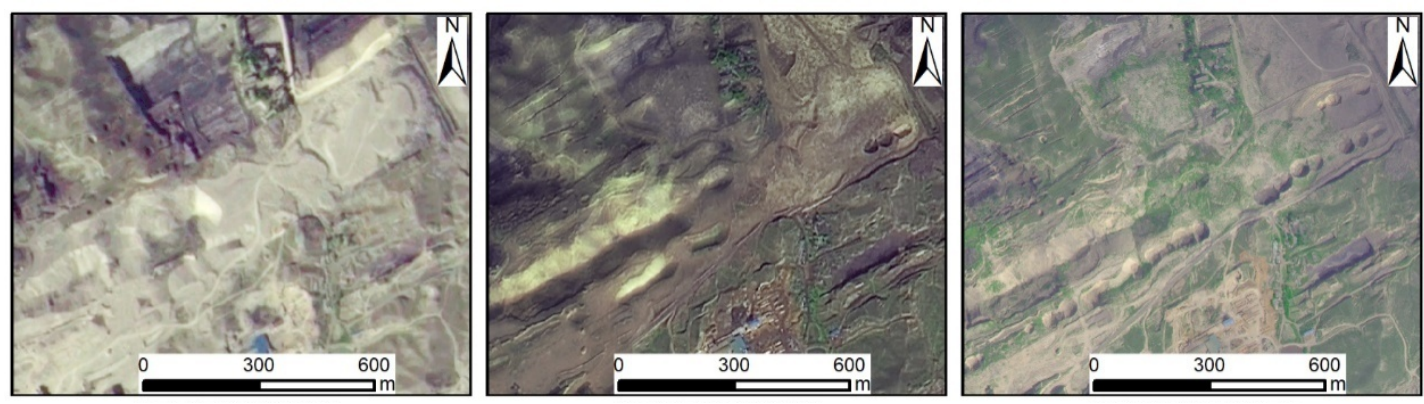

(a) Monitoring image in 2014 (b) Monitoring image in 2015 (c) Monitoring image in 2016

Fig.6 Dynamic monitoring change in Subsidence Area

Tab.3 Comparison of dynamic monitoring results in 2014-2016

\begin{tabular}{|c|c|c|c|c|}
\hline $\begin{array}{c}\text { Monitoring } \\
\text { year }\end{array}$ & $\begin{array}{c}\text { Collapse area } \\
\text { (place) }\end{array}$ & $\begin{array}{c}\text { Collapse pit } \\
\text { (place) }\end{array}$ & $\begin{array}{c}\text { Ground fissure } \\
\text { (place) }\end{array}$ & $\begin{array}{c}\text { Spontaneous combustion of coal } \\
\text { gangue }\end{array}$ \\
\hline 2014 & 8 & 169 & 8 & 1 \\
\hline 2015 & 8 & 173 & 8 & 1 \\
\hline 2016 & 9 & 180 & 10 & 3 \\
\hline
\end{tabular}

By the end of 2016, a total of 9 subsidence areas were found in the study area. Among them, there are 5 medium collapse areas and 4 small collapse areas. The

subsidence area harms 4 villages, one national road and one county road.

Tab.4 Survey results of Subsidence area in 2016

\begin{tabular}{|c|c|c|c|c|c|c|}
\hline coal mine & $\begin{array}{l}\text { Distribution } \\
\text { position }\end{array}$ & $\begin{array}{c}\text { Area of } \\
\text { Goaf } \\
\text { Collapse } \\
\text { Area } \\
\text { (ha) }\end{array}$ & $\begin{array}{c}\text { Collapse } \\
\text { pit } \\
\text { number } \\
\text { (place) }\end{array}$ & $\begin{array}{l}\text { Total } \\
\text { area of } \\
\text { collapse } \\
\text { pit (ha) }\end{array}$ & $\begin{array}{l}\text { Scale of } \\
\text { subsidence } \\
\text { area }\end{array}$ & $\begin{array}{c}\text { Impact } \\
\text { object }\end{array}$ \\
\hline $\begin{array}{l}\text { Xinjiang Dongfang } \\
\text { Jinsheng industry and } \\
\text { Trade Co., Ltd. Miquan } \\
\text { Sha Gou coal mine }\end{array}$ & $\begin{array}{l}1 \mathrm{~km} \text { in the north } \\
\text { of the dawning } \\
\text { city of East } \\
\text { China }\end{array}$ & 236.68 & 2 & 1.86 & Medium-sized & G30 \\
\hline $\begin{array}{c}\text { Xinjiang Henan coke } \\
\text { Energy Co., Ltd. } \\
\text { Urumqi Sanyuan coal } \\
\text { mine }\end{array}$ & $\begin{array}{l}\text { North } 1.2 \mathrm{~km} \text { of } \\
\text { stone mouth }\end{array}$ & 232.93 & 3 & 0.36 & Medium-sized & $\begin{array}{l}\text { Alkali Spring } \\
\text { Village, } \\
\text { X020 }\end{array}$ \\
\hline $\begin{array}{c}\text { Shenhua Xinjiang } \\
\text { energy limited liability } \\
\text { company Wu Dong } \\
\text { coal mine }\end{array}$ & $\begin{array}{l}\text { Xiaohonggou } \\
\text { Village }\end{array}$ & 537.22 & 137 & 9.44 & Medium-sized & $\begin{array}{l}\text { Xiaohonggou } \\
\text { Village }\end{array}$ \\
\hline $\begin{array}{l}\text { Wei Jiaquan Longde } \\
\text { coal mine, Miquan }\end{array}$ & Nan Gou Village & 273.97 & 6 & 1.59 & Medium-sized & Undiscovered \\
\hline $\begin{array}{l}\text { Shenhua Xinjiang } \\
\text { energy limited liability } \\
\text { company Wu Dong }\end{array}$ & $\begin{array}{l}\text { Xiaohonggou } \\
\text { Village }\end{array}$ & 144.71 & 10 & 0.4 & Medium-sized & $\begin{array}{l}\text { Xiaohonggou } \\
\text { Village }\end{array}$ \\
\hline
\end{tabular}




\begin{tabular}{|c|c|c|c|c|c|c|}
\hline coal mine & $\begin{array}{l}\text { Distribution } \\
\text { position }\end{array}$ & $\begin{array}{c}\text { Area of } \\
\text { Goaf } \\
\text { Collapse } \\
\text { Area } \\
\end{array}$ & $\begin{array}{c}\text { Collapse } \\
\text { pit } \\
\text { number } \\
\text { (place) }\end{array}$ & $\begin{array}{c}\text { Total } \\
\text { area of } \\
\text { collapse } \\
\text { pit (ha) } \\
\end{array}$ & $\begin{array}{l}\text { Scale of } \\
\text { subsidence } \\
\text { area }\end{array}$ & $\begin{array}{l}\text { Impact } \\
\text { object }\end{array}$ \\
\hline \multicolumn{7}{|l|}{ coal mine } \\
\hline $\begin{array}{l}\text { Miquan Shunyi coal } \\
\text { mine limited liability } \\
\text { company coal mine }\end{array}$ & $\begin{array}{c}\text { People } \\
\text { Chuang-tzu two } \\
\text { team }\end{array}$ & 33.5 & 6 & 0.11 & small-scale & $\begin{array}{l}\text { Red mizukou } \\
\text { Village }\end{array}$ \\
\hline $\begin{array}{c}\text { Xinjiang Yu Jiao } \\
\text { Energy Co. Ltd. } \\
\text { Urumqi three Coalmine }\end{array}$ & $\begin{array}{c}1.5 \mathrm{~km} \text { in the } \\
\text { southeast of the } \\
\text { village }\end{array}$ & 55.3 & 2 & 0.3 & small-scale & G30 \\
\hline $\begin{array}{c}\text { Shenhua Xinjiang } \\
\text { energy limited liability } \\
\text { company alkali gully } \\
\text { coal mine }\end{array}$ & $\begin{array}{c}\text { People } \\
\text { Chuang-tzu three } \\
\text { team in the } \\
\text { Northeast } 1.2 \mathrm{~km} \\
\end{array}$ & 16.15 & 13 & 0.51 & small-scale & Undiscovered \\
\hline $\begin{array}{c}\text { Miquan Xiangyang } \\
\text { Coal Mine, Xinjiang }\end{array}$ & Nan Gou Village & 45.61 & 1 & 0.16 & small-scale & $\begin{array}{l}\text { Nan Gou } \\
\text { Village }\end{array}$ \\
\hline
\end{tabular}

\section{Conclusion}

Based on the application of dynamic monitoring in coal mining subsidence area, the following conclusions are drawn:

The high satellite data made in China is suitable for remote sensing monitoring and investigation of large or local regional geological disasters, and it can show geological disasters such as mined subsidence and ground cracks.

The domestic high satellite data combination of different resolution rates and phases can be used to monitor the dynamic changes of the collapse of the goaf, and the appropriate satellite data can be selected according to the actual business needs, and the cost can be reduced on the premise of meeting the application.

The characteristics of the geological hazard interpretation established in this study are suitable for the geological hazard monitoring in the study area, and can quickly and accurately locate the location and scope of geological disasters. However, different regions, different tectonic belts and different developmental stages will affect the form of the collapse and development of the goaf. The interpretation signs proposed in this paper are not universality, and it is necessary to carry out a larger, more comprehensive and more systematic dynamic monitoring and study of the geological disaster of the high satellite data made in China.

Coal resources are abundant in the study area, and mining subsidence is becoming more and more serious. As of 2016, 5 medium-sized subsidence areas and 4 small subsidence areas were found, which caused damage to 4 villages, 1 national roads and 1 county roads. It is suggested that mining area planning should be carried out in advance, scientifically exploited, and more efforts should be made to restore control.

\section{Acknowledgements}

This paper is supported by Programs of China Geological Survey $(121201003000172718,121201203000160009)$

\section{References}

1. Li C Z,Nie H F,Wang J and Wang X H. A remote sensing study of characteristics of geologicol disasters in a mine. Remote Sensing for Land and Resources. 1:45-48

2. Ma X J,Yang Z A,Zhou L,Zhang P B and Zhang J G.2006.Remote sensing survey of geological hazards in the urban district of Fushun City.Geology In China, 33(5):1167-1173

3. Ning S Z,Wan Y Q and Sun S X.2008.A discussion of coal mining area subsidence and remote sensing monitoring.Coal Geology of China. 20(1),10-12

4. Wang Q J, Guo H D, Chen Y, Lin Q Z, Li H. 2013.Application of remote sensing or investigating mining geological hazards. International Journal of Digital Earth, 6(5):449-468

5. Wang L F.2014.Application study of domestic satellite data in the investigation of geological disasters.Beijing: China University of Geosciences (Beijing )

6. Zhao S H,Wang Q,Yang Y P,Zhu L. Wang Z T and Jiang D.2015. Demonstration and Study on the application of remote sensing monitoring for GF1 satellite. Satellite Application, 3:37-40

7. Lu Y G,Fan S L and Li C L.2015.Application GF-2 Satellite in romote sensing monitoring on mine exploitation in Tibet.Spacecraft recovery and Remote sensing,36(4):73-83

8. Peng L, Xu S N, Mei J J and Su F H. 2017. Earthquake-induced landslide recognition using high-resolution remotesensing images. Journal of Remote Sensing, 21(4): 509-518

9. Xiao Y.2017. Application of GF Series Satelites on Geological hazard monitoring in coal mining area.Hefei: Hefei University of Technology

10. Fan M,Sun X F and Su F H.2017. Application analysis of remote sensing dynamic monitoring for geological hazards in southwest mountainous areas 
using domestic high-resolution satellite data. Remote Sensing for Land and Resources,29 (s1) : 85-89

11. Huang W J,Wang L and Wang S Q.2013.Mapping satellite one image processing and the application research.Geomatics and Spatial Information Technology, 7 (36) : 114-116

12. Dong F X.2015.A brief analysis of high satellite and application in China. Satellite Application, 3: 44-48 